\title{
STUDY OF THE PROPERTIES OF PROTIC IONIC LIQUIDS TO BE APPLIED IN THE ENHANCED OIL RECOVERY
}

\section{ESTUDO DAS PROPRIEDADES DE LÍQUIDOS IÔNICOS PRÓTICOS PARA SEREM APLICADOS NA RECUPERAÇÃO AVANÇADA DE PETRÓLEO}

\author{
G. F. D. Ferreira ${ }^{1,3}$; C. B. M. Lima ${ }^{2}$; S. Mattedi ${ }^{1}$, L. C. L. Santos ${ }^{1}$; A. K. C. L. Lobato ${ }^{1,3, *}$ \\ ${ }^{1}$ Federal University of Bahia, Post-Graduate Program of Chemical Engineering, Salvador, Bahia, Brazil \\ ${ }^{2}$ Federal University of Bahia, Department of Chemical Engineering, Salvador, Bahia, Brazil \\ ${ }^{3}$ Salvador University, School of Architecture, Engineering and IT, Salvador, Bahia, Brazil \\ ${ }^{*}$ Ana Katerine de Carvalho Lima Lobato. Salvador University, School of Architecture, Engineering and IT, Salvador, Bahia, Brazil, Phone: +55 71 99264-8031 \\ e-mail address: ana.lobato@unifacs.br (A.K. C. L. Lobato).
}

\begin{tabular}{l} 
A R T I C L E I N F O \\
\hline Article history: \\
Received 2018-10-09 \\
Accepted 2018-12-20 \\
Available online 2019-04-25 \\
pa l a vras - ch $a v e$ \\
Petróleo \\
Líquido Iônico \\
Tensão Interfacial \\
Planejamento Estatístico \\
ke yw o rds \\
Petroleum \\
Ionic Liquid \\
Interfacial Tension \\
Statistical Designing \\
\end{tabular}

\begin{abstract}
A B S T R A C T
The oil industry faces challenges with reservoir oil retention after years of exploration. Therefore, recovery methods have been developed to produce residual oil, such as chemical methods (CEOR). Recently, ionic liquids have been gaining in visibility and it is expected that at CEOR, the Ionic Liquid (IL) will decrease the Interfacial Tension (IFT) between oil and water and increase the viscosity of the injected fluid. The aim of this paper is to study the ionic liquid [2HEA] [Hx] in order to evaluate the influence of its concentration and the salinity on the interfacial tension between oil and a solution of ionic liquid, through the statistical designing of experiments. It was verified that the IL [2HEA] [Hx] was able to decrease the interfacial tension between oil and the water solution and that both the ionic and salt concentrations were significant for the reduction of interfacial tension.
\end{abstract}

RES UM O/RES UMEN

A indústria de petróleo enfrenta desafios com a retenção de petróleo nos reservatório, após anos de exploração. Por isso, métodos de recuperação foram desenvolvidos para produzir o óleo residual, como os métodos químicos (CEOR). Recentemente, os líquidos iônicos vêm ganhando visibilidade e espera-se que, na CEOR, o Líquido Iônico (LI) diminua a Tensão Interfacial (TIF) entre o óleo e a água e aumente a viscosidade do fluido injetado. $O$ objetivo do trabalho é estudar o líquido iônico [2HEA][Hx] com o intuito de avaliar a influência da sua concentração e da salinidade na tensão interfacial entre o petróleo e uma solução de líquido iônico, através do planejamento estatístico de experimentos. A partir do planejamento, verificou-se que o LI [2HEA][Hx] foi capaz de diminuir a tensão interfacial entre o óleo e a água e que tanto a concentração de líquido iônico quanto a de sal foram significativas para a redução da tensão interfacial. 


\section{INTRODUCTION}

The oil industry faces some challenges such as the low efficiency at the production stage. This fact makes that after years of exploration, a great part of the oil remains retained in the reservoir. Therefore, several recovery methods were developed in order to produce the residual oil. Chemical methods (CEOR) are the most used for enhanced oil recovery (Sakthivel et al., 2015).

New materials with more cost benefit and less aggressive to the environment are being studied for application in the CEOR. Recently, Ionic Liquids (IL's) have been gaining much attention as an alternative to surfactants (Bera and Belhaj, 2016). At CEOR, the ionic liquid could decrease the Interfacial Tension (IFT) between oil and rock by changing the rock's wettability and increasing (in some cases) the viscosity of the injected fluid. IL draws attention to CEOR because of its properties as high thermal stability over a wide temperature range, non-flammability and solubility in many organic and inorganic compounds. IL's modified by the addition of an alkyl chain are considered for application in CEOR because of their ability to decrease interfacial tension and the ability to form micelles. Laboratory tests have shown that ionic liquids decrease interfacial tension even at high temperatures and high salinity (Hezave et al., 2013).

Bin-Dahbag et al. (2015) studied some properties of ionic liquids. The authors stated that ionic liquids should be water soluble and the phase diagram should be made between IL, water and oil along with interfacial tension tests. It is important to measure the IFT in different salt concentrations to identify the optimum salinity of the system. The study showed that as you increase the size of the alkyl chain of an IL increases the ability to reduce the IFT due to high surface activity.

Cao et al. (2015) and Mohammed and Babadagli (2016) studied the alteration of rock wettability by the addition of imidazole based ionic liquids. The results showed that the IL's changed the wettability of the rock from oil-wettable to waterwettable. Cao et al. (2015) suggest that the choice of IL for this purpose is based on reservoir rock charge. As the carbonates are positively charged, it is indicated to use a cationic IL to decrease its adsorption on the rock. For sandstones, it is advisable to use anionic IL's since there are already negative ions on the surface of the rock. Sakthivel et al. (2016) verified that the ionic liquids decrease the interfacial tension between the crude oil and the solution of ionic liquid. Displacement tests were performed using a mixture of IL, polymers, surfactant and salt noting its effectiveness to recover oil. Based on the information obtained in the literature, this study proposes the synthesis of the ionic liquid [2HEA] [Hx] in order to evaluate the influence of its concentration and salinity on the interfacial tension between oil and a solution of ionic liquid, through statistical designing of experiments.

\section{METHODOLOGY}

\subsection{Synthesis of Ionic Liquid}

The synthesis of Protic Ionic Liquid (PIL) was carried out following the methodology described by Ferreira et al., 2017, where it was based on the neutralization reaction between hexanoic acid and the 2-hydroxyethylanine base that gave the ionic liquid 2-hydroxyethyl ammonium hexanoate.

\subsection{Characterization of Ionic Liquid}

PIL was characterized by the methodology described by Ferreira et al., 2017, where the viscosity, specific mass, moisture content and Critical Micellar Concentration (CMC) were analyzed.

\subsection{Statistical Designing of Experiments}

Aiming to analyze which variables exert a greater influence in the reduction of interfacial tension, a statistic designing of experiments was carried out. In this study, the studied variables (independent variables) were concentration of salt $(\mathrm{NaCl})$ and concentration of ionic liquid in a solution containing deionized water. The response variable (dependent variable) was the interfacial tension between water and soybean oil. The operational conditions of the equipment used to evaluate the interfacial tension did not allow the use of crude oil in order to give reliable results. Therefore, soybean oil, a readily accessible substance, easy to handle and with low cost was used in these tests.

The method used was RCCD (Rotational Central Composite Design), following the matrix shown in Table 1.

Table 1 - RCCD matrix with independent variable levels.

$\begin{array}{ccc}\text { Tests } & \text { IL } & \text { NaCl } \\ 1 & -1 & -1 \\ 2 & 1 & -1 \\ 3 & -1 & 1 \\ 4 & 1 & 1 \\ 5 & -1.41 & 0 \\ 6 & 1.41 & 0 \\ 7 & 0 & -1.41 \\ 8 & 0 & 1.41 \\ 9 & 0 & 0 \\ 10 & 0 & 0 \\ 11 & 0 & 0\end{array}$

As can be seen in Table 1, 11 trials were performed, four factorial points, four axial points and three central points. Table 2 presents the maximum, minimum, and center point values used for each designing variable.

Table 2 - Values of the independent variables of planning.

\begin{tabular}{lccccc} 
Variation & $\mathbf{- 1 . 4 1}$ & $\mathbf{- 1}$ & $\mathbf{0}$ & $\mathbf{+ 1}$ & $\mathbf{1 . 4 1}$ \\
IL (PPM) & 100 & 14,624 & 50,050 & 85,476 & 100,000 \\
NaCl (\%) & 0 & 1.465 & 5 & 8.35 & 10 \\
\hline
\end{tabular}

\section{RESULTS AND DISCUSSIONS}

\subsection{IL Characterization Results}

The moisture content for the ionic liquid [2HEA] [Hx] 
was $0.25 \%$ by mass. The specific mass at $60^{\circ} \mathrm{C}$ was 999.64 $\mathrm{kg} . \mathrm{m}^{-3}$. The viscosity at $60^{\circ} \mathrm{C}$ was $128.78 \mathrm{mPa} / \mathrm{s}$. The [2HEA] $[\mathrm{Hx}]$ showed the $\mathrm{CMC}$ at 30,000 ppm when the surface tension was equal to $36.4 \mathrm{mN} / \mathrm{m}$.

\subsection{Statistical Designing Results}

Table 3 presents the results of performed tests.

Table 3 - Designing matrix for the ionic liquid [2HEA] [Hx].

\begin{tabular}{cccc}
\hline Tests & $\begin{array}{c}\text { IL } \\
(\mathbf{P P M})\end{array}$ & $\begin{array}{c}\text { Salt } \\
(\boldsymbol{\%})\end{array}$ & Interfacial Tension $(\mathbf{m N} / \mathbf{m})$ \\
\hline 1 & 14,624 & 1.46 & 11.5 \\
2 & 85,476 & 1.46 & 10.1 \\
3 & 14,624 & 8.54 & 12.4 \\
4 & 85,476 & 8.54 & 7.2 \\
5 & 100 & 5.00 & 15.6 \\
6 & 100,000 & 5.00 & 8.1 \\
7 & 50,050 & 0.00 & 11.9 \\
8 & 50,050 & 10.00 & 8.9 \\
9 & 50,050 & 5.00 & 10.8 \\
10 & 50,050 & 5.00 & 10.6 \\
11 & 50,050 & 5.00 & 10.3 \\
\hline
\end{tabular}

Thus, $\mathrm{R}^{2}$ was obtained in the value of 0.92034 , which shows that the model has statistical significance for this interval. In addition, it was concluded that the significant variables were IL concentration, $\mathrm{NaCl}$ concentration and the linear interaction between them. However, the quadratic effect of IL and $\mathrm{NaCl}$ concentration was not significant. A new regression was performed only with the significant variables and the results are presented in Table 4.

Table 5 shows the Analysis of Variance (ANOVA) used to evaluate the statistical significance of the model.

With the new regression, the new $\mathrm{R}^{2}$ value is lower than the first, but this decrease is expected due to the exclusion of some variables.

Table 4 - Estimated effect of variables and their interactions for [2HEA] [Hx] ignoring non-significant variables.

\begin{tabular}{|c|c|c|c|c|c|}
\hline Factor & Effect & $\mathbf{p}$ & $\begin{array}{c}-90 \% \\
\text { (Confide } \\
\text { nce } \\
\text { Limit) }\end{array}$ & $\begin{array}{c}90 \% \\
\text { (Confide } \\
\text { nce } \\
\text { Limit) }\end{array}$ & $\begin{array}{c}\text { Coeffi- } \\
\text { cient }\end{array}$ \\
\hline $\begin{array}{c}\text { Main } \\
\text { Interaction }\end{array}$ & 10.67 & 0.00000 & 10.13 & 11.21 & 10.67 \\
\hline $\begin{array}{c}\text { (1) LI } \\
(\mathbf{P P M})(\mathbf{L})\end{array}$ & -4.30 & 0.00035 & -5.57 & -3.03 & -2.15 \\
\hline $\begin{array}{l}(2) \mathrm{NaCl} \\
(\%)(\mathrm{L})\end{array}$ & -1.56 & 0.05248 & -2.83 & -0.29 & -0.78 \\
\hline $1 \mathrm{~L}$ by $2 \mathrm{~L}$ & -1.90 & 0.08000 & -3.69 & -0.11 & -0.95 \\
\hline
\end{tabular}

Table 5 - ANOVA for liquid [2HEA] [Hx].

\begin{tabular}{ccc|ccc} 
& $\begin{array}{c}\text { Sum of } \\
\text { squares }\end{array}$ & G.L & $\begin{array}{c}\text { Avarage } \\
\text { squares }\end{array}$ & F calc & $\begin{array}{c}\text { p- } \\
\text { value }\end{array}$ \\
\hline (1)LI (PPM) (L) & $\mathbf{3 7 . 0 1}$ & $\mathbf{1}$ & $\mathbf{3 7 . 0 1}$ & $\mathbf{4 1 . 3 0}$ & $\mathbf{0 . 0 0}$ \\
$\mathbf{( 2 )} \mathbf{N a C l}(\boldsymbol{\%})(\mathbf{L})$ & $\mathbf{4 . 8 7}$ & $\mathbf{1}$ & $\mathbf{4 . 8 7}$ & $\mathbf{5 . 4 4}$ & $\mathbf{0 . 0 5}$ \\
1L by 2L & $\mathbf{3 . 6 1}$ & $\mathbf{1}$ & $\mathbf{3 . 6 1}$ & $\mathbf{4 . 0 3}$ & $\mathbf{0 . 0 8}$ \\
Residue & 6.27 & 7 & 0.90 & & \\
Total SS & 51.76 & 10 & & & \\
\hline
\end{tabular}

$\%$ change explained $\left(\mathrm{R}^{2}\right)=0.87883 ; \mathrm{F}_{\mathrm{tab}}=\mathrm{F}_{0,10 ; 3 ; 7}=3.07$

Table 6 was constructed to compare the experimental values and the values calculated by the model.

Table 6 - Experimental and calculated values of interfacial tension for [2HEA] [Hx].

\begin{tabular}{cccc}
$\begin{array}{c}\text { Experimental } \\
\text { Tension / mN/m }\end{array}$ & $\begin{array}{c}\text { Calculated } \\
\text { Tension/ } \\
\mathbf{m N} / \mathbf{m}\end{array}$ & $\begin{array}{c}\text { Absolut } \\
\text { Error/ \% }\end{array}$ & $\begin{array}{c}\text { Relative } \\
\text { Error/ \% }\end{array}$ \\
\hline 11.50 & 12.65 & 1.15 & 10.03 \\
10.10 & 10.25 & 0.15 & 1.51 \\
12.40 & 12.99 & 0.59 & 4.78 \\
7.20 & 6.79 & -0.41 & -5.67 \\
15.60 & 13.71 & -1.89 & -12.09 \\
8.10 & 7.63 & -0.47 & -5.79 \\
11.90 & 11.78 & -0.12 & -1.04 \\
8.90 & 9.57 & 0.67 & 7.52 \\
10.80 & 10.67 & -0.13 & -1.18 \\
10.60 & 10.67 & 0.07 & 0.69 \\
10.30 & 10.67 & 0.37 & 3.62 \\
\hline
\end{tabular}

By analyzing the results and calculated errors, it is possible to admit that the model describes satisfactory results. Thus, after validating the model, the response surface and the level curve were plotted to better visualize the influence of the variables on the interfacial tension (Figure 1).

By analyzing Figure 1, it is possible to verify the decrease of the interfacial tension with the increase of the concentration of IL and the concentration of salt. The decrease in interfacial tension occurs most markedly at a higher salt concentration. This is because the [2HEA] [Hx] has a hydroxyl in its structure, consequently it has a higher affinity for water.

By adding salt, the dielectric constant of the water increases, reducing the affinity of the IL with the water, which causes that the ions of the ionic liquid tend to migrate preferentially to the interface of the liquid, decreasing the interfacial tension.

From Table 5, and taking the Fisher's test, the mean

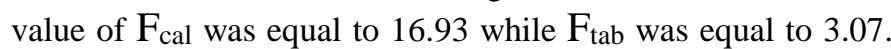
As $\mathrm{F}_{\text {cal }}>\mathrm{F}_{\mathrm{tab}}$, it can be said that the model is statistically significant. 
(a)

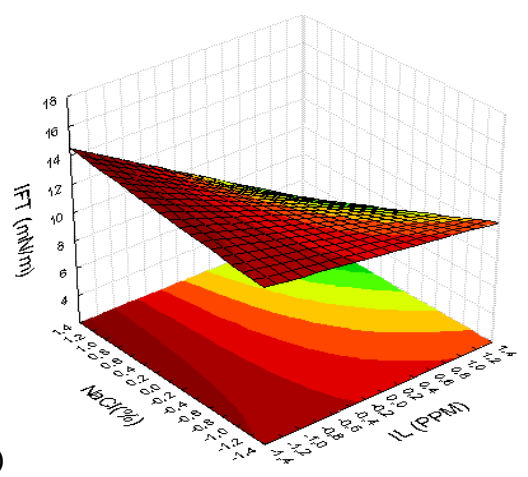

(b)

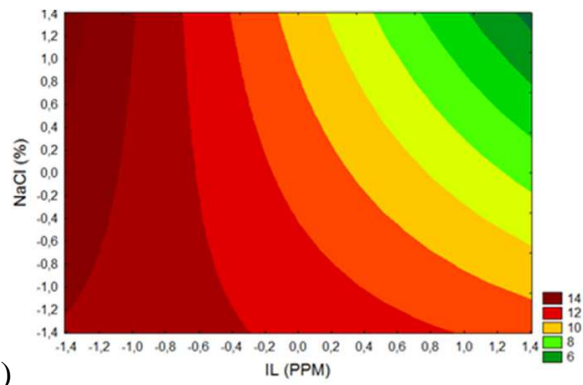

Figure 1 - Response surface (a) and level curve (b) for [2HEA] [Hx]

Following the mechanism described by Hezave et al. (2013) and Sakthivel et al. (2016) in salt-free solutions, there may be a repulsion between ions of the same charge. When this occurs, the IL is not able to distribute itself efficiently at the interface of the system, increasing the interfacial tension. However, as salt is added to the solution, the interfacial tension decreases, because the salt ions help to stabilize these repulsions that occur at the interface between the solution and the oil.

\section{CONCLUSION}

From the results obtained, it is possible to conclude that the model generated from the statistical design of experiments for the ionic liquid [2HEA] [Hx] was statistically significant. For this model, both the ionic liquid and salt concentrations were significant to decreases interfacial tension between water and oil. In addition, the ionic liquid was more efficient to reduce the interfacial tension in high concentrations of salt. Thus, the solution containing (PIL) may be used for future enhanced oil recovery tests.

\section{SPECIAL THANKS}

The authors are grateful to FAPESB/SECTI and CNPq (Process 306640 / 2016-3) for the financial support to carry out this article. In addition, this study was financed in part by the Coordenação de Aperfeiçoamento de Pessoal de Nível Superior - Brasil (CAPES) - Finance Code 001.

\section{R E F E R E N C E S}

BERA, A.; BELHAJ, H. A comprehensive review on characterization and modeling of thick capillary transition zones in carbonate reservoirs. Journal of Unconventional Oil and Gas Resources, v. 16, p. 7689, 2016.

BIN-DAHBAG, M.; ALQURAISHI, A.; BENZAGOUTA, M. Efficiency of ionic liquids for chemical enhanced oil recovery, Journal of Petroleum Exploration and Production Technology. v. 5, n. 4, p. 353-361, 2015.

CAO, N.; MOHAMMED, M.A.; BABADAGLI, T. Wettability Alteration of Heavy-Oil/Bitumen Containing Carbonates Using Solvents, High $\mathrm{pH}$ Solutions and Nano/Ionic Liquids, Paper OTC-26068-MS, Apresentado no OTC Brazil, Rio de Janeiro, Brasil, 2015.

HEZAVE, A.Z.; DOROSTKAR, S.; AYATOLLAHI, S; NABIPOUR, M.; Hemmateenejad, B. Investigating the effect of ionic liquid (1-dodecyl-3- methylimidazolium chloride $([\mathrm{C} 12 \mathrm{mim}][\mathrm{Cl}]))$ on the water/oil interfacial tension as a novel surfactante. Colloids and Surfaces A: Physicochemical and Engineering Aspects, v. 421, p. 63-71, 2013.

MOHAMMED, M.A; BABADAGLI, T. Experimental investigation of wettability alteration in oil-wet reservoirs containing heavy oil, SPE Reservoir Evaluation \& Engineering. SPE-170034-PA, v. 19, 2016.

SAKTHIVEL, S.; VELUSAMY， S.; GARDAS， R.L.; SANGWAI, J.S. Use of aromatic ionic liquids in the reduction of surface phenomena of crude oil-water system and their synergism with brine. Industrial Engineering Chemistry Resarch v. 54, p. 968-978, 2015.

SAKTHIVEL, S.; GARDAS, R. L.; SANGWAI, J. S. Effect of alkyl ammonium ionic liquids on the interfacial tension of the crude oil-water system and their use for the enhanced oil recovery using ionic liquid-polymer flooding. Energy \& Fuels, v. 30, n. 3, p. 2514-2523, 2016.

FERREIRA, G. F. D.; FERREIRA, P. I. S.; MATTEDI, S.; Santos, L. C. L.; Lobato, A. K. C. L. Avaliação das Propriedades de Líquidos Iônicos a Base de Hexanoato para Futuros Testes de Recuperação Avançada de Petróleo. IX Congresso Brasileiro de Termodinâmica Aplicada, CBTERMO 2017. 